\title{
IBN AL-BALAD (THE SON OF TOWN) TODAY
}

\author{
TAKEShI Hayashi \\ Councillor, Institute of Developing Economics
}

One of the Beirut merchants, who are world-famous for shrewdness and treachery, spoke about himself in the following manner: "Believe me I am not a Beiruti. My origin is ibn al-day'ah." He was very proud of it and people accepted him as trustworthy because of his origin. The word day'ah literally means a fertile land, but in this circumstance it is a small village or rural community. In opposition to the prevailing image of Lebanon as a mercantile nation descended from the Phoenicians, his phraseology proves that this country was and still is an agricultural society in which only her commercial activities could prosper. Reviewing occupational structure and the urbanrural distribution of the population this can be emphasized. Therefore, even today, the Lebanese sub-consciousness is deeply rooted in the community of the Mountains. And this significant social consciousness at the grass-root level forms a clear-cut contrast to the general hostility of communalism at the level of national politics and the power struggle under the hegemony of the $\mathrm{Zu}^{\prime} a m a$ ' (semi-feudal, old notables). The real cause of its social conflicts lies in the land problem but not in the religious sector. It was the maltreatment of Turkish administration and the interventions of big powers which diverted the real struggle into communal conflicts such as the Kesrawan revolts of peasantry in the middle of the last century.

It is strange to see in Egypt, where no one doubts about her agrarian nature, that in fact there does not exist any spiritual atmosphere in which ibn al-ard (son of the good earth) is praised. Peasants were, and are, called fellähin (tiller of land) since the Turkish ruling class once regarded all Egyptians as peasants (fellähin) and ra'iyah (subjects). Among the Egyptians, there were predominant trends which uphold the urban legacy and respected the son of the town (ibn al-balad).

In an analysis of Egyptian society, it will be useless to compare the above mentioned two cities, i. e., Cairo and Beirut, in the context of urban history, 
since Beirut was an Echelle of the Levant with just a century and a half years of career as the capital, and Cairo is a thousand-year-old great metropolis and was at one time called the city of the world. In this sense, it is more reasonable to characterize Cairo as one of the historic metropolises of the Arab-Islamic empire. However, no other city evokes such a strong sense of attachment on the part of citizenship and specifically towards the urban cultural legacy of Cairo. Neither in Damascus nor in Baghdad can we see the same coherent unique urbanism.

According to the Chronicle of al-Jabarti(1) and the descriptions of the society by E. Lane ${ }^{(2)}$ half a century after the Chronicle and of Stanley Lane-Poole's work ${ }^{(3)}$ two generations after Lane's study, the Cairenes preferred to call themselves awlad al-balad (pl. of walad al-balad, son of the town, the same as ibn al-balad). More accurately, they were not simple inhabitants of the city, but had certain traits in common. Ibn al-balad should be considered an Arab and not of Turkish or Frank origin; a Muslim and not a Coptic nor a Jewish; unprivileged, not a government or military official; an urbanite and not a bumpkins; a born Egyptian and not an immigrant from the other parts of the Arab-Islamic world.

"Ibn al-balad," then, refers to a specific, limited section of the population rather than the overall populace of Egypt. He was not an Alexandrite but an idealized Cairene, and consequently a typical Egyptian in his manners and outlook towards life and society and a believer in the Islamic faith, to which Jabarti himself belonged.

Almost all attributes of $i b n$ al-balad are respected by the present Cairenes as good old traits of citizenship. Lane-Poole considers them to be conservative. This statement must not be misunderstood. He saw many upper class Egyptians wearing Western suits and dancing with foreign ladies. They were "less Oriental in outward apperance and habits," but their "habits of tyranny, peculation, insincerity, and corruption" were of the Eastern autocrats. In keen contrast to them, the "conservative" shopkeepers and artisans keep up the old traditions of the society. This is the point he made, i. e., the populace as the bedrock of the good old Eastern way of life and culture. ${ }^{(4)}$

The shaikh of the Chronicle, al-Jabarti, provides us with an epic of the ibn al-balad, who rose in revolt several times against the tyranny of the then ruling foreign elements, the Mamluks, seeking liberty and justice from their rebellious nature. ${ }^{(5)}$ The characteristics of the typical Cairene, rebelliousness or disobedience to authority, have been regarded as an important attribute 
of the "son of the town," and it can be seen in their peculiar concept of freedom: a free-hearted, free-lance, out-spoken, free-willed attitudes towards the poor, towards the friends and guests, towards the control from outside or above, towards the sophisticated and snobs and towards the neighbourhood.

Freedom occupies the central position in the ethos of the ibn al-balad and constitutes the only source from which other indispensable traits of the competent Cairene have emerged and developed. The following are some examples:

1. Ibn al-balad hates the "Effendi"; originally this word meant government officials of high rank, but it is almost equivalent to employees who work for an organization with a fixed salary. This category of people is in service to a master; therefore their lives are in the hands of others. Ibn al-balad is the sole master of his work and life. "He lives his own life." His dignity comes from his own legitimate authority independent of others, especially of the superior and the rich. To him any job which harms his freedom is dirty and disgraceful. To live no-holds-barred and free from any assignment except spontaneous ones is the meaningful way to live. He does not care about the poverty caused by his carefree life, and is proud of being poor rather than being rich and under the supervision of others.

2. Ibn al-balad is a self-made man. $\mathrm{He}$ is a "hard-working" person, from early in the morning to late in the evening. He lives a very simple life and maintains a family by his own efforts. He is a "man among men." But the awläd al-Zawat (sons of the Turkish notables) were fed by their parents. Their property was inherited. Their wealth was sometimes accumulated by unfair means. They did not live their own lives, being lazy and stupid. This is the way the old Cairenes felt about their disgraceful life style.

3. Fellähin are not free men, since they are bound to the land and, even worse, since their social life is extremely limited and affords little chance to develop themselves in communication with the other social classes. In an urban setting people must be quick to grasp the changing situation and must be clever in order to be an independent social being. A keen sense of their society and rich experiences in human affairs build their dynamic personality.

4. Faced with hardships in business and in personal life, ibn al-balad is neither timid nor dumb. He takes the bad together with the good as it is. An important to him under such circumstances is to make his way through all circumstances with a good sense of humor and a though optimism.

These attributes are, all in all, attractive points of a good-natured citizen Vol. XIII 1977 
and are peculiar to the Cairene.

But then comes chivalry, as a rather inward orientated communal attitude of the ibn al-balad, in contrast to the concept of "freedom," which is orientated outward. The Cairene is not indifferent to the misfortunes and ills of his neighbors. Based on the principle of mutual help, sons of the town lend their hands and encourage the community members who suffer adversities. He must know well the actual situation of each family and must also be skilled in the treatment of folklore medication, as well as being knowledgeable about old manners and traditional etiquettes in order to handle such ceremonies as celebrations and funeral rites. Those talents were indispensable since the people were too poor to consult a doctor.

He plays a vital role when troubles arise among community members or with other communities. Ibn al-balad is expected to calm the disputes and eliminate the causes of the conflict, if possible, for his own community's benefit as a respectable leader. He must be a fair judge and mature arbitrator. His role is that of a counselor and a representative in intracommunity affairs and the inner problems. A good son of the town must be also a great master in the arts of war in addition to being a persuasive speaker. His good sense of humour and keen jokes and his full knowledge of folklore and anecdotes are the great assets in settling the disputes.

It is good for the community that it has many such able men. People respect him very much and are proud of him. Such a man is called an honourable $m u^{6}$ allim (teacher). Interesting enough is the fact that most of the $m u^{6}$ allims are owners of the baladi café or butchers. Although there are more educated people around, formal education in the spiritual and secular institutions does not affect the qualifications of a múallim, as can be seen from the above description. An important qualification of a mu'allim would be always to keep very close contact with the community and look after them.

The baladi café is, of course, a center for gossip and news which cover every corner of social and personal affairs. A café owner occupies the best position in the information network. There is no privacy in this; everything is discussed and all secrets are open secrets. But I am not certain why many mu'allims are butchers. It might have some relationship to the following points.

In inter-community relations, ibn al-balad makes all his efforts for the interest of his party. Good success in verbal battle with a quick outpouring of 
emotion is essential. In some cases, however, it ends up with fighting. This latter part of activity is, usually, left in the hands of another type of ibn al-balad. $\mathrm{He}$ is not a mu'allim but a futuwah. He voluntarily takes charge of escorting and protecting the daughters and children of the town from possible violence and insult by outsiders and foreigners, and also of dissuading against the use of force among the members. Sometimes he is a star or a hero or a prince of the district because of his deeds.

The gallant ibn al-balad also has other distinguishing features. It is most fashionable for him to wear moustaches and a neat gallabiyah (a loose, shirtlike garment) with turban and speak with a slightly different accents using rather husky low voices. He never intends to adjust to Western suits, which differentiate him from the upper and middle class components of urban Egypt.

This gallantry means clinging to the conventional and traditional nationalistic way of life which is closely related to the popular Islamic belief of antiintellectualism, which hates foreigners and non-Egyptian cultures. This is the reason why he was mobilized and misled by the Movement of Muslim Brethren and later became the victims of the fanatical religionists. However, his actual participation in the nationalist movement was seen during the 1919 Revolution, as was described by Russel Pasha; "The mob had barricaded streets in various parts of the town .... The Street ahead of me, just before the hospital, was barricaded with iron cradles torn up from round the street trees and beyond it I could see a howling mob of the most horrible-looking roughs I have ever seen .... It was composed of several thousands of the roughest elements of Cairo, all armed with something, some with knives and some with spearheads, chisels, adzes, tree-trunks, tree-props and so on, and those who had no weapons carried great jagged chunks of cast-iron gratings that they had torn up from round the trees; the only thing I did not see was firearms. The whole mob was shrieking and yelling and weaving their weapons in the air."'(6)

His gallantry, certainly, concerns women. At home, he behaves as the sole authority if he is the eldest in the family. He thinks that it is enough to protect the family from starving and to discipline only his sons and leave his daughters to his wife. His patriarchal posture means taking less care of family affairs than in the ordinary Western sense. But he is eager to have a large family and many sons, but if possible, only sons. The wife's obligation is to produce many children, and this is the best way to avoid estrangement. 
And he is extremely shy to express his affection to the family, especially towards his wife in public. It is rare to see a couple at a baladi cafés and theatres. In these respects, they share nothing in common with the Westernized high classes. Occasionally, his indifference and rude attitude towards a girl mean his hidden love for her. Such attitudes should be perceived by his mother, sisters and female relatives. The mother usually exercises much power in regard to the marriage of her son and his marital life.

The baladi husband is very proud of his ability to control his wife. Sometimes the wife is more than ten years younger and often more than twenty years younger. Generally speaking, the man gets married when he is middleaged, and the wife around her mid-teens. To middle-age man, who is socially esteemed and mature, the most disgraceful gossip is his wife's hysteria. People regard it as being caused by his lack of manliness, i. e., his wife's dissatisfaction with sex. The old dog fades away from the public scene and loses authority within the family, then comes into existence a "petticoat government," which is the end of gallantry.

Ibn al-balad is very fond of baladi (local produce) foods and dishes, i. e., eggs, pigeon, green wheat, ta'miyah, etc. The adjective baladi, here, means the most fresh, the most nourishing and the most nourishing and the most excellent. They stimulate lust as the Cairene would say. Egyptian fresh fruits and vegetables have very good reputation in quality and are available thoughout the year in a great variety; baladi foods are served a lot at each meal, but they have two meals only, morning and night, usually. Hashish is considered as the most baladi aphrodesiacs and no wife would mind an addict husband.

The districts where ibn al-balad concentrates are mostly the centuriesold quarters of Cairo, which used to be comprised of more than fifty small communities (härah) on the basis of ethnic-sectarian groupings and of guild organizations in the last century. This way of groupings provided the most important element in fostering a coherent unity among the community members. It is now not easy to find a family which has been living in the same härah over four or five generations back. This is not only because of the lack of reliable documents of family histories, but also by radical changes which occurred after the 19th century in particular, each härah witnessed a high mobility of population and a decline of indigenous industries and disorganization of old guild systems. A huge influx of peasants who lost their lands, moreover, moved into the folk areas of the urban settings. Inter-härah movement and new 
migration have changed the community's internal composition, and the new town planning has produced a drastic alteration in the ecological map of the outside metropolis, e. g., the disappearance of canals from the heart of the city. Cairo has grown into an enormous city of the nation far more rapidly than the natural growth of her population.

With the expansion of the city size, härahs had lost their autonomy as a socio-ecomic as well as administrative unit, and also splitted fragments which were much more smaller than the sub-härahs and had become almost equal to the darbs (i. e. lanes). The new härah is no more an autonomous unit but rather a neighbourhood with loose tie.

Since the initial stage of her industrialization after Wolrd War I, and especially during the Second War, the city experienced an unprecedented level of urbanization and development in the outskirts and suburbs, some of which had been since the latter half of the last century occupied by the new rural gentry, and the urban nouveau riches also left their old residential areas. Social differentiation has progressed during the inter-war period with tremendous speed in every section of the national society. New waves of migrants from the rural areas came into Cairo and were absorbed into the newly developed folk districts which differed in that they were composed, for the most part, of unskilled industrial workers of rural origin. It was rather a kind of ruralization process in the metropolis. In the district of Shubra, for example, they live with large families and sheep, and also revived polygamy which was rarely seen in other working class districts, such as in the Būlaq which developed in the 19th century and is today in a sense a baladi quarter outside the old baladi city. The developing enclaves of rural life next door to the centuries-old quarters and the emergence of extremely Westernized urban enclaves in the further outer sections in both the North and the South of the 19th century Cairo characterize the 20th century urban map of the city.

In the greater metripolitan area, the tensions between the old and the new, the traditional and the modern, the Eastern and the Western elements have been intensified at various levels and to various degrees, under internal and international pressures. The old poor Cairenes had to face with a new socioeconomic and political transformation process, which was characterized by disorder and mal-adjustment, particularly after the world depression of 1929.

In the midst of social change and flux, but the new scope being not yet established, they were inclined to restore the good old principles of the com- 
munity. People's efforts to defend it from the chaos gave rise to resurrectionoriented movements and new socio-religious movements. It was the time when some of the futuwahs turned into the baltagi (gangster). Usually they were manipulated by big bosses of outlaw organizations and baltagis pretended to be futuwahs. On the pretext of providing protection, they asked for money from the härah inhabitants and exploited the weak and poor. Usually, big bosses behind the scenes had a very close tie with the government's high officials and political leaders. The Moslem Brethren enjoyed its superior influence over the populace of Cairo, who were mainly small shopkeepers, artisans and lumpen proletariat, and these sectors suffered seriously from the course of developments, meanwhile only a small part of the baladi merchants made large profits and shifted to new areas and changed their way of life to that of the upper middle class.

Life of ibn al-balad was deeply rooted in the vulgar doctrine of the Islamic faith. They believe that they are under the protection of Muslim saints and patrons who were attrached to the districts, for instance, Hussain and Zainab. We can see here in a latent form elements of the sympathy and support which went to the emotional drive of the Moslem Brethren's religious fundamentalism.

Condemning the corrupt society and supporting the recovery of social justice, the Moslem Brethren appealed to the social resentment of the lower classes. But their social resentment drifted towards the justification of vandalism and introduced anarchy into the party, owing to their emotionalism and weakness in organization. From the lack of political maturity in the leadership, fanaticism took over the whole movement at the peak of the mass participation. In this chaos, their self-assured futuwah changed into baltagi. The ibn al-balad is by nature not a group of people who are politically ambitious. They have been always an object of politics, and not a subject. Although they were, and are, "rebellious," their political attitudes have never been revolutionary, but only just disobedient and dutiless. So the political commitment of the futuwah is valuable insofar as it was confined to their limited small society, härah. Only within this small sphere, futuwah's political attitudes were meritorious. Their naive pride of Egyptian nationhood inclined to turn into xenophobia and to the scorn of the "infidels," which could be seen in the 40's nationalism among the mass.

We cannot unfortunately find a good social sense among the ibn al-balad in the last century, when they looked down the peasantry. Of course, this 
signifies rapid urbanization and a changing social character of the ibn al-balad with the influx of rural elements and their mal-adaption to the new environment. The old and new elements did not mix well. In this respect, we have to pay more attention to the nature of political parties in Egypt; it was the Sa'dist Party that brought the Brethren, and especially Alī Māher Pasha, into the field of politics as maneuver to check the other parties.

The population of the greater Cairo metropolitan area had already reached more than six million (it was a million and a half a century ago). The most modern residential area in the latter half of the 19th century, Exbekiyah, has become a folk area long ago which had been connecting the two parts of the mediaeval and the then modern sectors of the working class, Husain and Boulaq.

An Englishman, who lived in Bab el-Luk during the war stated a couple of years ago that he found that already succumbed to the "fellahin tide." A young student of urban geography leads off his description on showing surprise that the Bab el-Luk was a frangi (Franks, and foreign) area at that time.

Rural exodus still continues as it has even after the land reform had introduced a great changes in the village. Statistics show that there is either no difference or a slightly higher rate of fertility between the urban and the rural areas, which is contrary to the world-wide trends of lower birth rates in the metropolis. Experts point out the inaccuracy of data for the village. Even if this is so, the rate must still be almost the same. This is an interesting subject for further study. Nevertheless, there is a clear evidence, on the other hand, concerning ruralization in the Egyptian capital in parallel with rapid urbanization. Electricity in the villages made people go to bed late from listening to radio programmes, people in the folk area were not early risers today according to the remarks of an English Arabist in the last century. (7)

Today Zamalek is not a place for the frangi, and Gezira Club is open to Egyptians. But baladi people felt that the district as a colony of frangis and of mutafarnigis (Westernized, snobbish Egyptians), and in the folk songs ibn al-balad scorns them. The queen of folk singing, Umm Kalthum, lived there in the neighbourhood filled with frangi diplomats, and engineers from socialist countries, and embassies which are transferring from the Garden City, a product of French town-planning before World War I.

Dokki, which is not regarded as a baladi quarter and is put in the same category as other districts like 'Abbasiyah, Pyramids, Gizza, has smoothly Vol. XIII 1977 
changed character. It is one of the newly developing areas for the middle and lower middle classes. The President of the U. A. R. lives there more than decades and a new American hotel opened for business several years ago. Since the Six-Day War, Heliopolis has lost its value due to the air raids of Israelis, but still has luxurious and snobbish upper middle class residences: one of my informants from this area regarded the $i b n$ al-balad as a poor Cairene and a gangster.

The ex-British town Ma'adi is Americanized today, since private traffic facilities are good to live there. Interesting to read is the address book of the staff and graduates of the American University in Cairo. More than $90 \%$ of them are concentrated in the above mentioned highly residential areas and none of them came from the baladis. But I know several students, men and women, of the university who call themselves awläd al-balad in the good old sense. On the other hand, Cairo University has many staff members and students coming from families of ibn al-balad and a good many students including females from landless peasant families.

The drastic reforms since the 1952 revolution have been taking place in higher education and is exercising influence on the life of the ibn al-balad. The old Cairenes did not esteem formal schooling, putting more emphasis on actual experience in business and life. The new generation educated free of charge and in secular ways threatens the patriarchal authority of the family head. They are equipped with a scientific outlook and are free from the older generations' qadar (fatalism); and also, more important is the fact that they earn a fairly substantial amount of money. Even girls wish to have higher education and government or other jobs as security against the weak marital status of women (e. g., in case of divorce). Among them, the new type of ibn (bint) al-balad have been appearing. Recent university graduates are not quasizawatis, nor effendis, but rather a new, open-minded class. In this sense, the new ibn al-balad is essentially equal to the common Egyptians with no prejudice against the rural origin.

In parallel with the changing views among the university men and intellectual circles, common people are indicating a new definition of the term. Nowadays, ibn al-balad is not confined to someone born in Cairo of Cairene parents, nor to Egyptian parents. Furthermore, children born and raised in the old quarters are all competent to be awläd al-balad. An ibn al-balad who is respected as a typical member of the community by his neighbours, is likely to 
be of the Christian faith; but we can see nothing different from other Moslems in his daily life. In Ramadan he fasts. In the "Chronicle" al-Jabarti speaks of a Magreb Arab as a paragon of ibn al-balad with his excellent deeds and manners. Thus essential to an ibn al-balad are his personality and behaviour, and not his ethnic and/or religious origin: This might be a marginal case, however.

This is the reason why in the most common usage ibn al-balad means an Egyptian, rather than a Cairene. And, a new term, al-sha'ab (people), has been taking its place after the Arab Socialist Declaration of 1961.

The term $a l-s h a^{\prime} a b$ is a rather politically orientated phrase invented by the government but not yet completely integrated. Its political references are workers and peasants; both are organized along the policy lines at the level of trade unions and cooperatives. Ibn al-balad, disjointed, "politically inactive," and merely critical and dutiless, became a minor entity in the national politics.

Ibn al-balad has been in the limelight of the Egyptian film and stage over the past several years as a less stupid and warm-hearted Cairene. $\mathrm{He}$ is portrayed as a gangster, and a humourous humanist, in a comical and nostalgic way in both leading and supporting roles. I think some Egyptian intellectuals express their criticisms of the government, through this portrayal of the $i b n a l$ balad. But the people responsed cooly to such exercises and are sometimes critical, because the portrayal does not accurately depict the actual lives of the people.

However, it might be wrong to assume that they will simply fade away in a changing society. It may be mistaken to expect them to play a significant sole in society. The old type Cairene will survive as a type of urbanite and his sub-culture will remain intact, though somewhat more amorphous than in the past. A democratic government must be more sensitive to its voiceless citizens. If the political élites fail in this, the $i b n$ al-balad will revolt in desparation. Their language and grammar differ from both the Arab socialism of the Egyptian middle class, and from the Western mode of democracy. On the other hand, they have a more mature approach towards evaluating the social, cultural and political environment in which they live. 


\section{Notes}

(1) Abd al-Rahman al-Jabati; 'Ajä'ib al-ätār fil-tarājim wa-l-akhbār, Būlāq. $1927 \mathrm{AH}$ (1880)

(2) Lane; The Manners and Customs of the Modern Egyptians. London (1835)

(3) Stanley Lane-Poole; Cairo, Sketches of its History, Monuments, and Social Life. London (1892)

(4) S. Lane-Poole; op. cit. p. 124

(5) Jabarti; op. cit. Vol. 1, p. 107

(6) Russel Pasha; Egyptian Service 1902-1946. London (1949) p. $202 \mathrm{ff}$.

(7) E. Lane; op. cit. p. 156 (Everyman's Library Ed. 1966) 